\title{
Transnational Education: Trend, Modes of Practices and Development
}

\author{
Pi-Yun Chen
}

\begin{abstract}
Transnational education is becoming a popular form of international higher education cooperation since late 1990s. Many universities from the developed nations are increasingly focusing on entrepreneurial activities by exporting their higher education to those developing societies with the exceed demands for higher education. Along with the recent innovations in information and communication technology, the international mobility of programs and institutions on a large scale since 1990s is becoming a special phenomenon while students mobility is continuing to grow in international higher education. As a form of academic mobility and market driven educational activity, transitional education is following the same pattern as international student mobility the major English speaking countries, such as UK, USA and Australia, are the primary and key service providers. However, the rising of regional hubs along with the entry of those countries without colonial and linguistic background like Taiwan is changing the landscape of transnational higher education.
\end{abstract}

Index Terms-AInternational higher education, transnational education, offshore program, modes of delivery, regional hub.

\section{INTRODUCTION}

Transnational education is a fast growing global phenomenon as it provides internationally recognized education at the doorstep of students [1]. It has become a widely recognized concept as new delivery models of education that cross borders emerge, bearing political, economic and cultural implications along its practices [2].

As identified by many scholars, there are three distinct waves of globalization in the international education industry. As identified by many scholars, there are distinct waves of globalization in the international education industry. The first and also the most common model refers to students' travelling to a host nation to study at the chosen institutions. The second involves institutions moving forward into the export channel and establishing a presence in the international markets through 'twinning program' [3] or offshore degree courses and training. This model became common especially in Asia as well as the developing countries throughout 1990s with many privately owned institutions offering outlets for students to study the foreign degrees in their home country [4]. The third and also a relatively new approach emerges with the establishment of international branch and offshore campus in foreign countries as well as the development of online courses delivered through information and communication

Manuscript received March 9, 2014; revised June 27, 2014.

Pi-Yun Chen is with the Graduate School of Finance, Shu-Te University, Taiwan (e-mail: pc112@stu.edu.tw). technologies [5].

According to its working definition, transnational education is to describe the programs and courses "in which the learners are located in a county that is different from where the awarding institution is based" [6], [7]. Along with the recent innovations in information and communication technology, the international mobility of programs and institutions on a large scale since 1990s is becoming a special phenomenon while student's mobility is continuing to grow in international higher education.

\section{TREND}

Against the development of the global economy along with new impact brought about by the new managerial ideology, higher education has become more aggressive with market domination orientation [2]. As a result, the strong element of a "mutually beneficial cultural movement" in the international education [2] was observed to replace the military offense and cultural conquest featured in the conventional international education in the colonial era. As a result, the shift from providing financial support and educational aid to the developing nations to recruiting fee paying international students from those counties was then identified in the educational policies of many western societies. The tuition fees generated from international students, either through traditional manners or transnational education practices, have become an important source to compensate for insufficient resources resulted from domestic financial cuts. As a result, transnational has become not only a new form of international collaboration in education but also a source of income for many universities around the world, especially in the western developed nations.

The promotion made by the World Trade Organization (WTO) since 1995 is believed to have made great impact on the liberalization of trade, including trade in educational service, which has brought higher education and other forms of tertiary educational into the global trade framework. It is argued by many that WTO's promotion has provided an international institutional safeguard for the development of transnational education [1], [2], [8]. The global needs for education, training and research are driving the worldwide mobility of peoples for different reasons. As it is observed that the worldwide demand for higher education is growing and is being driven by the economic growth in developing societies, increased globalization of economic and societies along with the demographic trends [1]. According to official figures provided by UNESCO, the students' number participating in higher education from 1990 to 2007 has grown by $128 \%$ [9] and the number is still rising. 
The transnational provision of education during the past decade, as Yang argues [10], has increased dramatically that is at the leading edge of the most fundamental change taking place in higher education today. It is also evidencing the invisible hand of the market in allocating educational resources across borders effectively, marking a new evolutionary phase of development in international higher education in the 21 stcentury.

\section{MODES OF DELIVERY}

The innovative nature of transnational education is manifested not only in the breakthrough in the philosophy, strategic development plan and institutional operations, but also in the cooperation models between the institutions across the nations and the emergence of new delivery modes of transnational programs.

There are four modes of supply, according to the barriers to trade, defined in General Agreement on Trade in Services [11]. They are cross-border supply, consumption abroad, commercial presence and presence of natural persons. Transnational higher education is however closely connected with two modes mentioned above, including cross-border supply and commercial presence, implemented in numerous forms.

- Cross border supply: it includes approaches such as online learning programs and distance delivery. Those programs are mainly delivered through satellites, televisions, computers, internet, video conference or other technological means within or beyond the national boundaries.

- Commercial presence: several forms that have been popularly adopted include branch or satellite campus, franchises, twining arrangements and so on. Apart from branch campuses set up by an institution in another country to provide its educational or training programs to foreign students directly [8], the rest of forms in the commercial presence mode are somehow depending on various levels of partnership involvements. The partner-supported delivery depends more heavily on partnership with various kinds of service that often include face-to -face teaching, physical facilities and administrative support locally [7], as shown in Table I.

Based on the modes of supply categorized by in GATS, many [2], [8], [7], [10] have identified the popular modes of delivery widely used in transnational education. There include a) branch campus, b) articulations, c) online learning and distance education programs, d) franchising and partnership, and e) dual and joint degree programs.

- Branch campus: this refers to campuses set up by an institution in another country to provide its educational or training programs to the foreign students, mainly in that host country. This arrangement is on the one hand allowing the degree offering institution to conduct educational activities more effectively but on the other hand it is costly in comparison with other modes of delivery and requires more financial commitment.

- Articulation programs: The articulation refers to systematic recognition by an institution from the degree offering country of specified courses/ programs/ study at an institution in another country as partial credit towards a program at the offering institution. With this arrangement, the students are enrolled initially with the local/host institution and subsequently enroll with the foreign provider along with the awarding qualifications.

- Online learning and distance education programs: Under this delivery mode, programs and courses are delivered through televisions, satellites, radios, computers, conferencing, and other technological means across national boundaries.

- Franchising and partnership: This mode often involve a local provider being licensed to offer the foreign courses and programs under conditions set out by contract with the qualification awarded by the foreign institution from the source country. All arrangements relating the program delivery, including teaching, management, assessment, profit-sharing or qualification requirements and so on, are practiced in compliance with the policy as well as the regulations of the two sides, both the host and source countries.

- Dual and joint degree programs: Under this scheme, education providers from different countries work together to offer joint training programs and the students receive qualifications from the both providers, or a joint award from the collaborating partners.

TABLE I: MODE OF SUPPLY

\begin{tabular}{|c|c|c|c|}
\hline $\begin{array}{l}\text { Mode of } \\
\text { supply } \\
\text { according to } \\
\text { GATS }\end{array}$ & Explanation & $\begin{array}{l}\text { Example } \\
\text { in Higher } \\
\text { Education }\end{array}$ & $\begin{array}{l}\text { Size/ Potential of } \\
\text { market }\end{array}$ \\
\hline $\begin{array}{l}\text { 1. Cross Border } \\
\text { Supply }\end{array}$ & $\begin{array}{l}\text { - the provision } \\
\text { of a service } \\
\text { where the } \\
\text { service } \\
\text { crosses the } \\
\text { border (does } \\
\text { not require the } \\
\text { physical } \\
\text { movement of } \\
\text { the consumer) }\end{array}$ & $\begin{array}{l}\text {-distance } \\
\text { education } \\
\text { - e-learning } \\
\text {-virtual } \\
\text { universities }\end{array}$ & $\begin{array}{l}\text {-currently a } \\
\text { relatively small } \\
\text { market } \\
\text { - seen to have } \\
\text { great potential } \\
\text { through the use } \\
\text { of new ICTs and } \\
\text { especially the } \\
\text { internet }\end{array}$ \\
\hline $\begin{array}{l}\text { 2. Consumption } \\
\text { Abroad }\end{array}$ & $\begin{array}{l}\text {-provision of } \\
\text { the service } \\
\text { involving the } \\
\text { movement of } \\
\text { the consumer } \\
\text { to the country } \\
\text { of the supplier }\end{array}$ & $\begin{array}{l}\text {-students who } \\
\text { go to another } \\
\text { country to study }\end{array}$ & $\begin{array}{l}\text {--currently } \\
\text { represents the } \\
\text { largest share of } \\
\text { the global } \\
\text { market for } \\
\text { education } \\
\text { service }\end{array}$ \\
\hline $\begin{array}{l}\text { 3. Commercial } \\
\text { Presence }\end{array}$ & $\begin{array}{l}\text {-- the service } \\
\text { provider } \\
\text { establishes or } \\
\text { has presence } \\
\text { of commercial } \\
\text { facilities in } \\
\text { another } \\
\text { country in } \\
\text { order to } \\
\text { render service }\end{array}$ & $\begin{array}{l}\text {-local branch or } \\
\text { satellite } \\
\text { campuses } \\
\text {-twinning } \\
\text { partnerships } \\
\text {-franchising } \\
\text { arrangements } \\
\text { with local } \\
\text { institutions }\end{array}$ & $\begin{array}{l}\text { - growing } \\
\text { interest and } \\
\text { strong potential } \\
\text { for future } \\
\text { growth } \\
\text { - most } \\
\text { controversial as } \\
\text { it appears to set } \\
\text { international } \\
\text { rules on foreign } \\
\text { investment }\end{array}$ \\
\hline $\begin{array}{l}\text { 4. Presence of } \\
\text { Natural Persons }\end{array}$ & $\begin{array}{l}\text {-persons } \\
\text { travelling to } \\
\text { another } \\
\text { country on a } \\
\text { temporary } \\
\text { basis to } \\
\text { provide } \\
\text { service }\end{array}$ & $\begin{array}{l}\text {-professors, } \\
\text { teachers and } \\
\text { researchers } \\
\text { working abroad }\end{array}$ & $\begin{array}{l}\text { - potentially a } \\
\text { strong market } \\
\text { given the } \\
\text { emphasis on } \\
\text { mobility of } \\
\text { prefessionals. }\end{array}$ \\
\hline
\end{tabular}

(source: The Observatory on borderless higher education, knight, 2002) 


\section{Mapping The CuRRent DeVelopment}

The global demand for education, training and research is believed as the driving force behind the worldwide mobility of peoples for, as Alam et al observed, "migration, political and economic security, trade and business, employment, tourism, study and research" [1], [12].

The increasing worldwide demand for higher education is driven by the fast economic growth in the developing nations demographic trends in the globalization era [12]. Based on the current trends in the increasing global mobility of students, it is anticipated that the number of international students will continue to grow to 6.7 million by the year 2020 [13], [14].

As a result of the reduction of government subsidies, however, universities around the world are increasingly focusing on entrepreneurial activities and many western universities in particular have become heavily dependent onshore fee paying international students as well as export-oriented educational services in partnership with universities, professional associations and private cooperation offshore [1], [2], [8], [12], [15]-[18]. The exceed demands for higher education in most developing societies with continuing rising need is seen as the push factor whereas the surplus of education and the financial short fall in the universities of developed nations has been recognized as the pulling factor. It is with such push and pull factors at various levels that transnational education could take its shape and grow dramatically.

As a form of academic mobility and market driven educational activity, similarly, many have found that transitional education is following the same pattern as international student mobility where highly developed nations, such as the major English speaking countries, UK, USA and Australia, are the primary and key providers of the transnational education service whereas Asia is believed to be the receiving region with the most active participation in transnational education along with other emerging economies also include Middle East, North Africa, South America and so on. This verified the analysis in many studies that the demand for higher education in the emerging economic where the growing young population, such as China and India, is putting pressure on domestic educational systems to which transnational education from the developed western nations is seen as the immediate solution [1], [2], [7], [10]-[12], [14], [17], [19].

Transnational education is observed to follow the trend of international education where the major English speaking nations, the UK, USA, Australia and so on, are still the key players for attracting international students. Exporting education service through different modes of co-operation to those countries with excess demands for higher education is the most common strategy adopted. The consolidated official data shown in Garrett and Verbik's work verifies the above statement and at the same time clearly indicates the size and distributions of transnational education enrollment. Continental European countries, nevertheless, tend to act on 'regional integration and complement with each other on their strength' [2] in the current development of transnational education instead of putting the full gears on educational service exporting.

\section{The Changing Landscape}

In the recent development, the emergence of regional hubs for transnational education is adopted as an approach to make the foreign higher education available locally at an affordable price. By deregulating higher education with the introductions of market mechanism, many governments are attracting leading universities from the western world to offer their programs for local students as well as from the regional. By doing so, these countries are able to increase educational export and at the same time act as the hosting countries for international students from the region through importing.

As a result, five regional hubs are identified within which most foreign universities are concentrated. These include 1) Singapore and Malaysia; 2) China and Hong Kong; 3) India, Bangladesh and Pakistan; 4) United Arab Emirates and Qatar, and 5) South Africa [1]. By arguing that "the rise of transnational higher education in the Asia-Pacific region has undeniably reflected the growing pace of globalization and the subsequent pressures imposed by it", Mok observed the governments of Singapore, Malaysia and Hong Kong, among others, are three notable cases in which the states have explicitly declared their intentions respectively to make these Asian countries/ territory a regional hub of education, competing for its position in this competitive global market of international higher education, thus led to a rather dramatic development of transnational higher education accordingly in recent years as part of the states' coping strategies [19] .

The emergence of regional hubs, as many argue [1], [19], are not changing the demography of the student cohort but also bringing impact on curriculum design, related facility and infrastructure accordingly.

In addition to the rise of the regional hubs, the entry of the countries without neither colonial nor English speaking background in the current move of transnational education is not only changing the current landscape but also adding more diversity in this education service sector. Dozens of universities from Taiwan, for example, have presented themselves possessing the capability of offering competitive and quality offshore higher education programs at home and abroad.

Internationalization is advocated as an important development strategy not only by the government but also individual universities in Taiwan as going international is becoming an inevitable trend in the current global context. However, it is necessary to note that it appears to be more critical in the context of Taiwan as many universities, public or private alike, has been facing serious storage of student recruitments resulted from the decreasing birth rate since late 1990s, in addition to the reduction of government subsidies to universities. Seeing from the context of Taiwan, thus, transnational education is therefore taken as a great opportunity in seeking for alternative source of student number as well as financial support [20].

\section{CONCLUDING REMARKS}

Many believe that transnational education helps to develop its human resource capital with the least cost but pressure on local education systems the receiving countries. On the other hands, the warning over the challenges and possible dangers 
posed by transitional education are also given in several studies, mainly with the voices of those from the receiving countries. These include eroding educational sovereignty, threatening the cultural security, and the social as well as economic impact and so on. [2], [8], [10], [19]. However, it is certain that the current move in the international higher education will continue to generate student mobility between the developed and developing nations. In addition to these major English-speaking counties, the emergence of regional hubs and the entry of those without colonial and linguistic bond are not only changing the demography of the student cohort but also changing the landscape of this education service.

\section{REFERENCES}

[1] F. Alam, Q. Alam, H. Chowdhury, and T. Steiner, "Transnational education: benefits, threats and challenges," Procedia Engineering, vol. 56, pp. 870-874, 2013.

[2] J. Gu, "Transnational education: Current developments and policy implications," Frontiers of Education in China, vol. 4, no. 4, pp. 624-649, 2009.

[3] D. Smart, "Recruitment and financing of candidates to study overseas: The case of Malaysia and its implications for Australia," Australian Universities Review, vol. 2, pp. 26-30, 1988.

[4] C. Prystay, "Boom in university twinning across Asia," Asian Business, vol. 32, no. 9, pp. 60-63, Sept. 1996.

[5] T. Mazzarol, "Critical success factors for international education marketing," The International Journal of Educational Management, vol. 12, no. 4, pp. 163-175, 1998.

[6] Council of Europe. (2001). Code of Good Practice in the Provision of Transnational Education. (Adopted by the Lisbon Recognition Convention Committee at its second meeting, Rīga, 6 June 2001). [Online]. Available: http://www.coe.int/t/dg4/highereducation/recognition/code $\% 20$ of $\% 20$ good\%20practice_EN.asp

[7] G. McBurnie and C. Ziguras, Transnational Education: Issues and Trends in Offshore Higher Education, Abingdon: Routledge, 2007.

[8] F. Huang, "Transnational higher education: A perspective from China," Higher Education Research \& Development, vol. 22, no. 2, pp. 193-203, 2010.

[9] UNESCO. (2009). Institute of Statistics, UIS Database. [Online]. Available: http://unctad.org/fr/Docs/gdscsir20041_en.pdf.

[10] R. Yang, "Transnational higher education in China: Contexts, characteristics and concerns," Australian Journal of Education, vol. 52, no. 3, pp. 272-286, 2008.

[11] J. Knight, "Trade on higher education services: The implications of GATS," The Observatory on Borderless Higher Education, pp. 1-24, 2002.

[12] F. Alam, A. Subic, A. Plumb, M. Shortis, and R. Chandra, "An innovative offshore delivery of an undergraduate mechanical engineering program in developments," Engineering Education Standards: Advanced Curriculum Innovations, IGI Global, USA, pp. 233-245, 2012.

[13] A. Calderon, "Emerging countries for student recruitment in tertiary education," presented at the IMHE-OECD Conference on Higher Education in a World Changed Utterly: Doing More with Less, Paris, 2010.

[14] OECD. (2010). Education at a Glance. [Online]. Available: http://www.oecd.org/document/52

[15] P. Y. Chen, "Internationalization of higher education: Development of offshore programs in Southeast Asia," Taiwan Educational Review Monthly, vol. 2, no. 1, pp. 18-22, 2013.

[16] B. R. Clark, Creating Entrepreneurial Universities: Organisational Pathways of Transformation, Oxford: Elsevier, 1998.

[17] D. Poole, "Moving towards professionalism: The strategic management of international education activities at Australian universities and their Faculties of Business," Higher Education, vol. 42, no. 4, pp. 395-435, 2001

[18] S. Slaughter and L. L. Leslie, Academic Capitalism: Politics, Policies and the Entrepreneurial University, Baltimore: Johns Hopkins University Press, 1997.

[19] K. H. Mok, "The quest of regional hubs of education: Searching for new governance and regulatory regimes in Singapore, Hong Kong and Malaysia, East-West," Senior Seminar on Quality Issues in the Emerging Knowledge Society, Malaysia, October 2009.

[20] P. Y. Chen, "Strategic Management for transnational higher education in Taiwan," in Proc. the Firth Asia Conference on Education, Osaka, pp. 23-27, October 2013.

Pi-Yun Chen was born in Kaohsiung, Taiwan in 1971. She received her postgraduate education at Department of Educational Studies, University of York, UK from 1994 to 2000. She has been working in the fields of multiculturalism and social development, multicultural education, cross-cultural marriages, cultural competence and international education. In addition to the long-term devotion in the multicultural reform movement in Taiwan education, she has involved in many research projects across borders concerning the cross-cultural marriages in South East Asia, especially Vietnam.

During her terms as the international office director at Meiho University and followed as the overseas vice president at Shu-Te University, Taiwan, she was in charge of the international education in general and the transnational education in particular from 2005 to 2012. With the direct management for both Meiho and Shu-Te university's offshore programs in Vietnam, the author was able to gain the first hand experiences in transnational expansions and learn how the universities from Taiwan, without its colonial backgrounds, could find its position in this competitive market and its ways for sustainable development. Benefiting from the years of involvement in international education and transnational expansions, the author is now the international representative at Shu-Te University, supporting the strategic planning for its internationalization. Dr. Chen is now a faculty member at Graduate school/Department of Finance, Shu-Te University, Taiwan. 